\title{
Mitigation of greenhouse gas emissions in the French winter oilseed rape in order to produce sustainable biodiesel
}

Francis FLÉNET

CETIOM,

Avenue Lucien Brétignières,

78850 Thiverval-Grignon,

France

$<$ flenet@cetiom.fr $>$

\begin{abstract}
The objectives of the study were (1) to evaluate the possibility for the French winter oilseed rape to achieve the $50 \%$ greenhouse gas (GHG) saving criteria of the European Directive on the promotion of renewable energy (2009/28/EC), and (2) to investigate mitigation options. The agricultural GHG emissions were calculated with the actual seed yields and cultural operations of more than 5000 winter oilseed rape fields producing seeds collected by 27 grain storage companies (GSC), while the same values of GHG emissions for transport and biodiesel processing were used for all GSC. The study clearly showed that the 50\% GHG saving criteria could not be achieved each year, by each of the grain storage company, without improvements of crop management. The possibility to reduce the GHG emissions by improving the efficiency of mineral $N$ fertilization was demonstrated. Improving seed yields without increasing the amount of $\mathrm{N}$ application on the fields would also decrease GHG emissions. On the contrary, the application of organic matter appeared to be largely ineffective because of the way $\mathrm{N}_{2} \mathrm{O}$ emissions were calculated in the study (tier 1 method of International Panel on Climate Change).
\end{abstract}

Key words: Greenhouse gas, winter oilseed rape, biodiesel, sustainability criteria, seed yield, $N$ nutrition

not taken into account. Moreover, the GHG emissions could be calculated each year for each grain storage company (GSC). Hence, "low GHG" crop managements would probably be necessary in order to achieve the 50\% saving criteria each year in each GSC, especially if an iLUC emission value was taken into account.

The first objective of the study was to evaluate the possibility for each grain storage company to achieve the 50\% GHG saving criteria in each year. The second objective was to investigate mitigation options: (1) improving the efficiency of mineral $\mathrm{N}$ fertilization or (2) applying organic matter (OM).

\section{Material and methods}

In order to evaluate the possibility for each grain storage company to achieve the $50 \%$ GHG saving criteria, the agricultural GHG emissions were calcu- lated with the actual seed yields and cultural operations to produce the rape seeds collected by each GSC, while the same values of GHG emissions for transport and biodiesel processing were used for all GSC.

The GHG calculations were made for 27 GSC located in the main French regions producing oilseed rape. In each GSC, a survey was conducted in 2010 to collect data on seed yields and cultural operations. On average, about 200 fields were surveyed in each GSC, resulting in a total number above 5000 fields for the 27 GSC.

The cultural operations recorded in order to calculate the GHG emissions were tillage (tools used for tillage and number of tillage operations), the application of glyphosate during the fallow period before the sowing of the rapeseed crop (number of applications and amount of glyphosate), the 
application of organic matter (amount and $\mathrm{N}$ content) and the application of mineral $\mathrm{N}$ fertilizer. The type of soil was also recorded.

The fuel consumption for tillage, and the resulting GHG emission, as well as the GHG emissions resulting from the production of tillage tools and from the use of engine oil, were calculated using published data on fuel and engine oil consumptions by each type of tillage tool, depending on the type of soil, and on energy consumption for tool production (Godron, 1992; ITCF, 1995). The GHG emissions due to the application of organic matter, as well as those resulting from harvest, were also calculated using the data of Godron (1992) and ITCF (1995).

Herbicide, insecticide, fungicide and growth regulator applications were not recorded, except for glyphosate, because the GHG emissions resulting from the production and application of these products are low compared to the total emissions. Hence, an average GHG value for all fields could be used without great effects on the accuracy of the total GHG emission values. This average value was calculated from a previous survey on the application of chemicals on winter oilseed rape, and from data on GHG emissions for the production of these chemicals (Green, 1987; Gaillard et al., 1997). The fuel consumption, the production of tools and the use of engine oil to apply chemicals were also taken into account. The glyphosate applications were recorded, because the resulting GHG emissions are greater than those of other chemicals, similar to those of some tillage operations, and because the amount of glyphosate is negatively correlated to tillage (more glyphosate is applied in low tillage systems).

The GHG emissions due to $\mathrm{N}$ fertilization accounted for both the production of the fertilizers and their application on the fields. The emissions from the production of fertilizers greatly depend on the technology and on the source of fossil energy used for this production. Hence, the values used in this study were typical values for the French agriculture (Gac et al., 2009). Typical French values for $\mathrm{P}_{2} \mathrm{O}_{5}$ and $\mathrm{K}_{2} \mathrm{O}$ fertilizer production were also used, but the amounts of these fertilizers were estimated, instead of being surveyed, because the amounts applied are often crops. For instance, in soils with high levels of $\mathrm{P}_{2} \mathrm{O}_{5}$ and/or $\mathrm{K}_{2} \mathrm{O}$, farmers may apply no fertilizers. Farmers may also apply those fertilizers on oilseed rape aiming both the fertilization of this crop and of the following cereal crops. Hence, the amounts of $\mathrm{P}_{2} \mathrm{O}_{5}$ and $\mathrm{K}_{2} \mathrm{O}$ used in the GHG calculations were estimated from the output (i.e. seed yield multiplied by percentages of $\mathrm{P}_{2} \mathrm{O}_{5}$ and $\mathrm{K}_{2} \mathrm{O}$ in the seeds which are respectively $1.34 \%$ and $1 \%$ ).

The $\mathrm{N}_{2} \mathrm{O}$ emissions by soils were estimated, using the Tier 1 method of the International Panel on Climate Change (De Klein et al., 2006). The emissions of the processing of biodiesel and of the transports were the mean values for France published by $\mathrm{BIO}$ IS (2010), which are respectively 7.1 and $1.47 \mathrm{~g} \mathrm{CO}_{2}$ eq. MJ ${ }^{-1}$. This GHG emission value of the processing of biodiesel is three times lower than the standard value of the European Directive 2009/ 28/EC, because the French units of processing are more efficient than most European units. Moreover, the value of the European Directive is $40 \%$ greater than the average European value, in order to force biofuel producers to use real values. No other emissions were taken into account (i.e. carbon stock changes caused by iLUC, soil carbon different from the amounts needed by

accumulation via improved agricultural management. ..).

The GHG emissions were allocated between the main product (biodiesel) and the co-products according to their energy content, as it is recommended in the European Directive 2009/28/EC. The GHG saving value of rapeseed biodiesel (GHG_S) was calculated from the estimation of the emissions of this biofuel (GHG_B) and from the emissions of fossil diesel which are $83.8 \mathrm{~g}$ $\mathrm{CO}_{2}$ eq. MJ) (European Directive 2009/ 28/EC): GHG_S $(\%)=100 \cdot(83.8-$ GHG_B)/83.8.

In order to study the year effect on seed yield, the statistics of the past five years were taken into account (2006-2010). During this period, the French mean oilseed rape yield ranged from 2.90 to $3.78 \mathrm{t} \mathrm{ha}^{-1}$, and the 2010 yield $(3.27 \mathrm{t}$ $\mathrm{ha}^{-1}$ ) was quite a medium value: the highest and the lowest mean yields were respectively 1.16 and 0.89 times as great as the yield observed in 2010 . Hence, the GHG emissions with $85 \%$ or $115 \%$ of the seed yields recorded in 2010 in each grain storage company were calculated under the hypothesis that the cultural operations were the same (the actual operations surveyed in 2010 were used in the calculations). The GHG emissions were also calculated with $30 \mathrm{~kg} \mathrm{~N} \mathrm{ha}^{-1}$ less mineral fertilizer

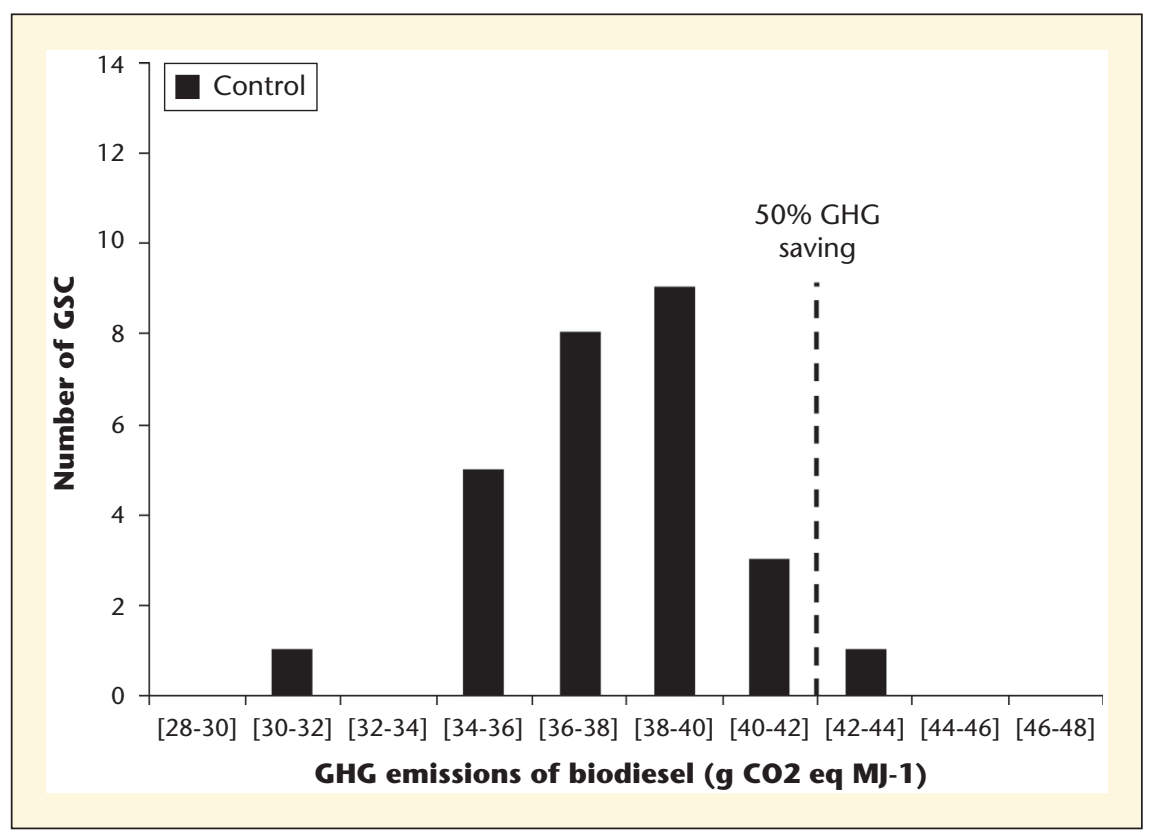

Figure 1. Biodiesel greenhouse gas (GHG) emissions of grain storage companies (GSC). Control: GHG calculations made with the actual values of crop managements and seed yields. For each range of GHG emissions, the number of GSC showing such values is reported. 
without any effect on seed yield. The application of $50 \mathrm{~kg}$ of organic $\mathrm{N} \mathrm{ha}^{-1}$ was also studied, because this amount could be applied before sowing with little risk of increasing nitrate leakage. Two hypotheses were tested: (1) the fertilizer efficiency of organic $\mathrm{N}$ was the same as that of mineral $\mathrm{N}$ or (2) $50 \%$ lower, resulting in a decrease in mineral $\mathrm{N}$ fertilizer of 50 or $25 \mathrm{~kg} \mathrm{~N} \mathrm{ha}{ }^{-1}$ respectively.

\section{Results and discussion}

The greenhouse gas emissions of biodiesel ranged from 30-32 to $42-44 \mathrm{~g}$ $\mathrm{CO}_{2}$ eq. $\mathrm{MJ}^{-1}$ (figure 1 ), depending on the grain storage company collecting the rapeseed. Hence, in 2010 the 50\% GHG saving criteria was achieved for all GSC except one. However, the number of GSC failing to fulfil this sustainability criteria would have been greater if the iLUC effect had been taken into account. The variability of GHG emissions was mainly explained by differences in $\mathrm{N}$ applications and in seed yields. For instance, the lowest GHG emission was obtained with a slightly higher rapeseed yield than the average yield of the 27 GSC (3.7 vs. $\left.3.6 \mathrm{t} \mathrm{ha}^{-1}\right)$ and with a lower $\mathrm{N}$ application (165 vs. $196 \mathrm{~kg}$ of total $\mathrm{N}$ ha $^{-1}: 101$ vs. $164 \mathrm{~kg}$ of mineral $\mathrm{N} \mathrm{ha}^{-1}$ and $64 \mathrm{vs} .32 \mathrm{~kg}$ of organic $\mathrm{N} \mathrm{ha}^{-1}$ ): data not shown.

The year effect on GHG emissions could not be directly studied from the survey which was only conducted in one year. The issue is about the effect of the variability in seed yields and in cultural operations between years apart from the long term trends which is another issue. In oilseed rape in France, the variability in seed yields is one of the greatest among the main crops cultivated in this country. On the contrary, there is little variability in cultural operations between years, especially in the amount of $\mathrm{N}$ applied which explains almost $90 \%$ of oilseed rape GHG emissions (data not shown). Hence, in winter oilseed rape the year effect is mainly an effect of the climatic conditions and of the biotic stresses on seed yields. This can be studied using national seed yield statistics, as long as a short period of time is taken into account in order not to take into account the long term increasing yield trend. In this study, GHG emissions were calculated with yields $15 \%$ lower or $15 \%$ greater

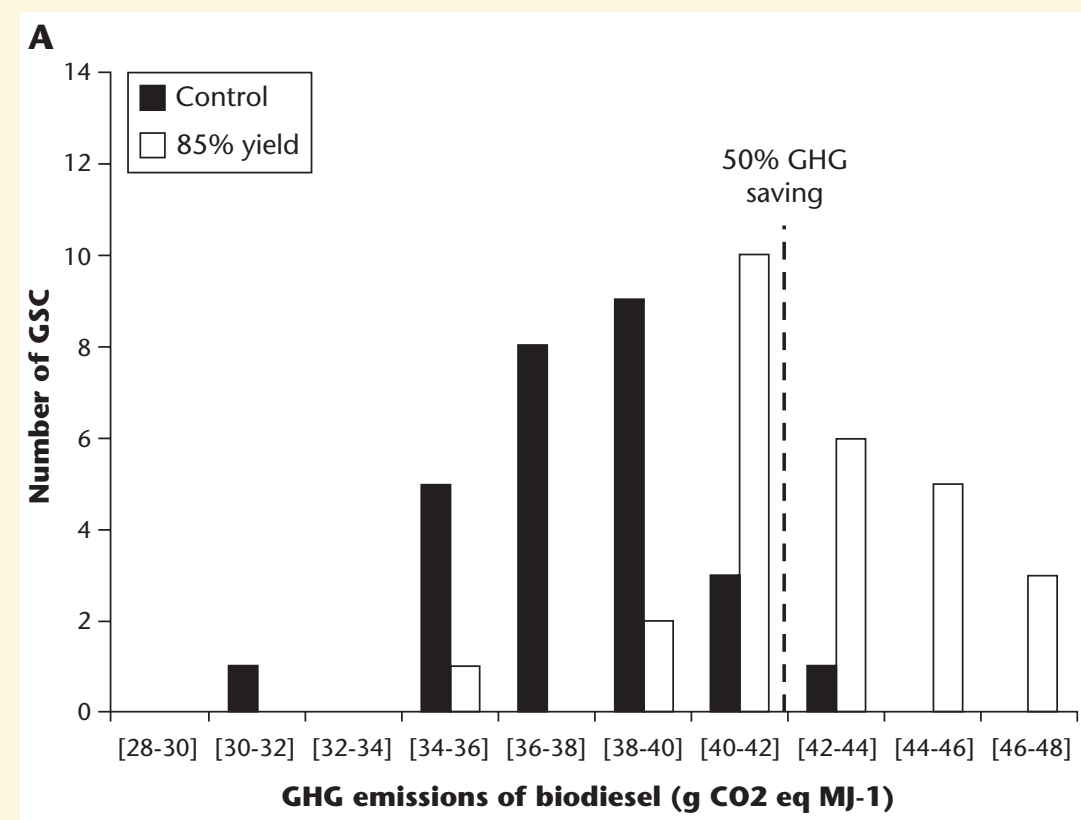

B

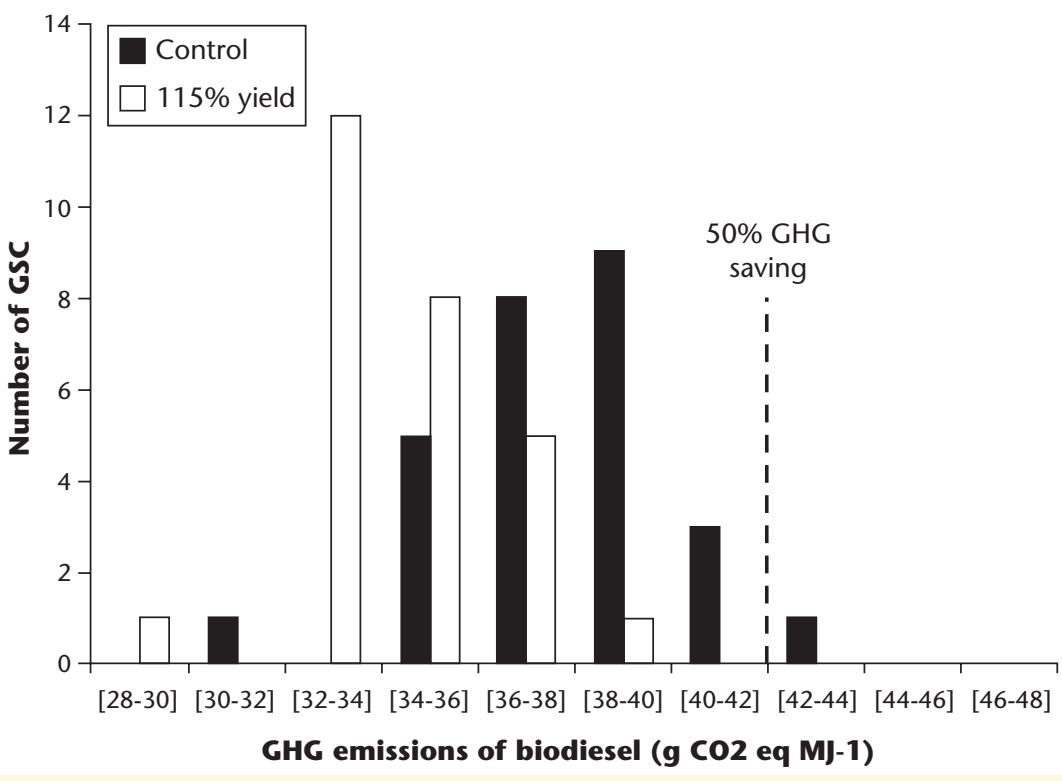

Figure 2. Effect of oilseed rape seed yield on GHG emissions of biodiesel. For each range of GHG emissions, the number of GSC showing such values is reported for calculations with the actual seed yields (control), and for $15 \%$ less $((a), 85 \%$ yield) or $15 \%$ more yield ((b), $115 \%$ yield).

than the actual yields of the 27 grain storage companies, which is a rough estimate of the seed yield variability within the past five years in France (see the Material and methods section). A major year effect was observed, because in the low yielding year ( $85 \%$ yield) the GHG saving was lower than $50 \%$ in half of the GSC (figure $2 A$ ), while the lowest
GHG saving was above $54 \%$ in the high yielding year (115\% yield) (figure $2 B$ ). These results show that ways of decreasing the emissions must be found in order to achieve the $50 \%$ GHG saving criteria each year in each GSC.

The improvement of $\mathrm{N}$ fertilizer practices is still an important issue for oilseed 
rape cultivated in France, because almost $50 \%$ of the French farmers do not use any method to calculate the amount of mineral $\mathrm{N}$ fertilizer that is needed (CETIOM survey). Moreover, some farmers who use a method apply a higher amount of $\mathrm{N}$ fertilizer than the calculated value. According to those surveys on $\mathrm{N}$ fertilizer practices, on average the application could be decreased by $30 \mathrm{~kg} \mathrm{~N} \mathrm{ha}^{-1}$ with almost no effect on seed yield. The effect of such a decrease is shown in figure 3. It is quite similar to the year effect on seed yield. Hence, such an improvement in the efficiency of $\mathrm{N}$ fertilization should make possible the achievement of the $50 \%$ GHG saving criteria for each GSC in each year. In France, a $10 \mathrm{~kg} \mathrm{~N}$ ha $^{-1}$ decrease in the application of mineral fertilizer was observed from 1996 to 2005 (Reau, 2006) due to the development of a calculation tool that takes into account the $\mathrm{N}$ already uptaken before the application of fertilizer. More rapid changes in the practices are needed. Hopefully, the obligation to reduce the GHG emissions of oilseed rape in order to reach the biofuel sustainability criteria will result in an extended and in a better use of the $\mathrm{N}$ fertilizer calculation tools.

The application of organic matter (OM) may also be a way of reducing the GHG emissions of oilseed rape, because it replaces some mineral $\mathrm{N}$ fertilizer and hence it decreases the $\mathrm{CO}_{2}$ emitted due to the use of fossil energy to produce these fertilizers. Moreover, the production of fertilizers containing nitrate also emits $\mathrm{N}_{2} \mathrm{O}$. However, the application of $\mathrm{OM}$ may result in increased $\mathrm{N}_{2} \mathrm{O}$ emissions by soils. According to the Tier 1 method of the International Panel on Climate Change (De Klein et al., 2006), which was used in this study, the direct emissions due to the application of organic $\mathrm{N}$ are the same as those due to mineral $\mathrm{N}$ fertilizer ( $1 \%$ of applied $\mathrm{N}$ is emitted as $\mathrm{N}-\mathrm{N}_{2} \mathrm{O}$ ). Moreover, indirect emissions resulting from $\mathrm{NO}_{3}{ }^{-}$leakage and from $\mathrm{NH}_{3}$ or $\mathrm{NO}_{x}$ emissions are even greater with organic $\mathrm{N}$ than with mineral N. Hence, the OM application may not result in a reduction of GHG emissions if its $N$ fertilizer efficiency is lower than that of mineral $N$. In order to study the ability of OM application to reduce GHG emissions, depending on its $N$ fertilizer efficiency, the effects of either a same efficiency as that of mineral $\mathrm{N}$ (figure $4 A$ ) or an efficiency

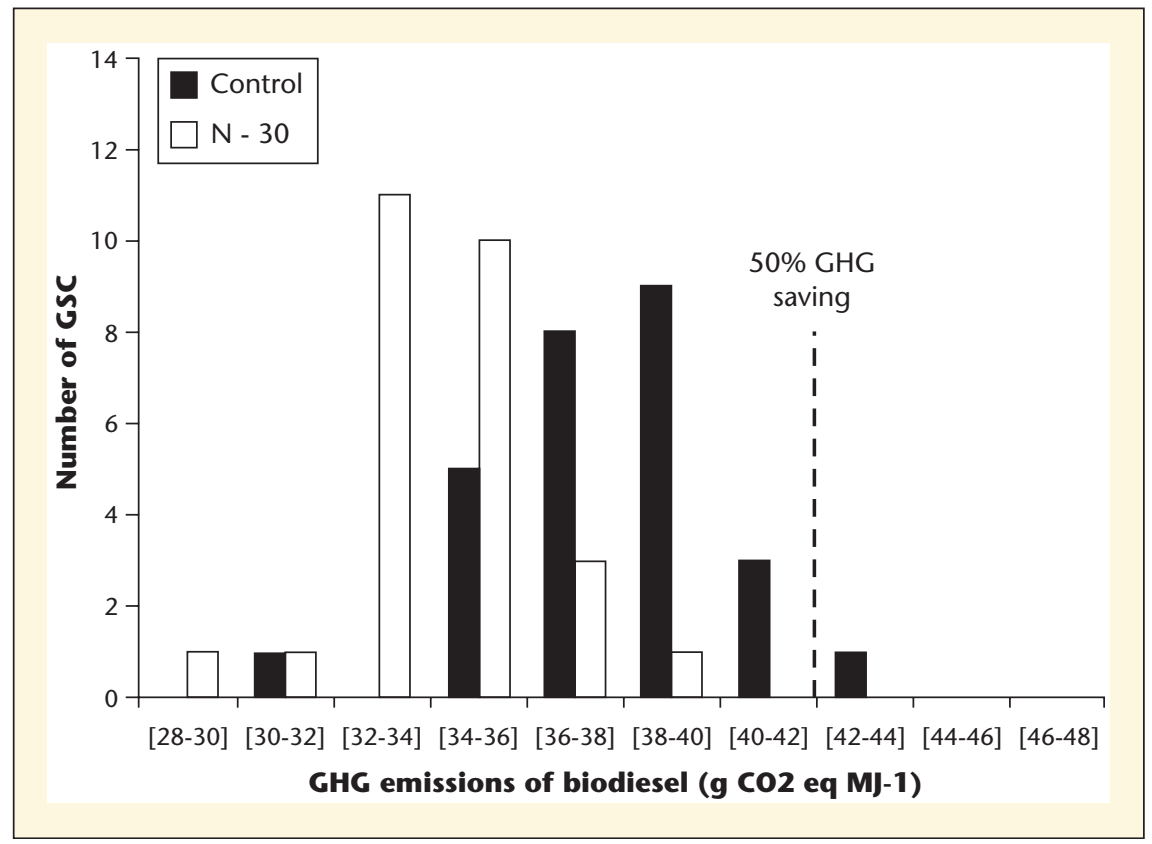

Figure 3. Effect of the amount of mineral $N$ fertilizer applied on oilseed rape crops on GHC emissions of biodiesel. For each range of GHG emissions, the number of GSC showing such values is reported for calculations with the actual amount of $N$ (control) and for $30 \mathrm{kgN} \mathrm{ha}{ }^{-1}$ less $(N-30)$.

$50 \%$ lower (figure 4B) were studied. As expected, the application of OM is an interesting way of reducing the GHG emissions if its $\mathrm{N}$ efficiency is as high as

that of mineral $\mathrm{N}$. On the contrary, an application of OM with a $50 \% \mathrm{~N}$ fertilizer efficiency, compared to mineral $\mathrm{N}$, results in increased $\mathrm{GHG}$ emissions.

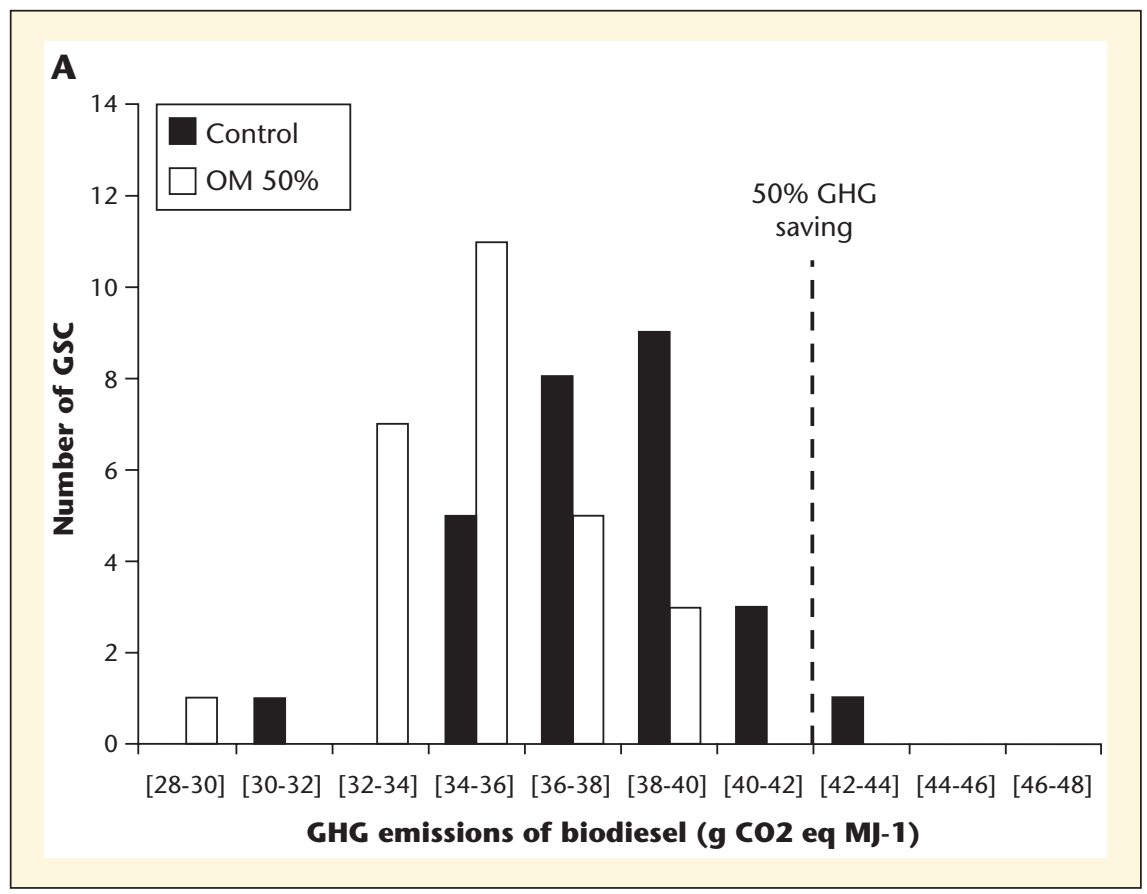

Figure 4. Effect of the application of organic matter (OM) on oilseed rape crop on GHC emissions of biodiesel. For each range of GHG emissions, the number of GSC showing such values is reported for calculations with the actual OM and mineral $N$ applications, and for 50 $\mathrm{kgN} \mathrm{ha} \mathrm{s}^{-1}$ more as organic $N$ with a fertilizer efficiency as high as that of mineral $N((A), O M$ $100 \%)$ or $50 \%$ lower ((B), OM 50\%). 


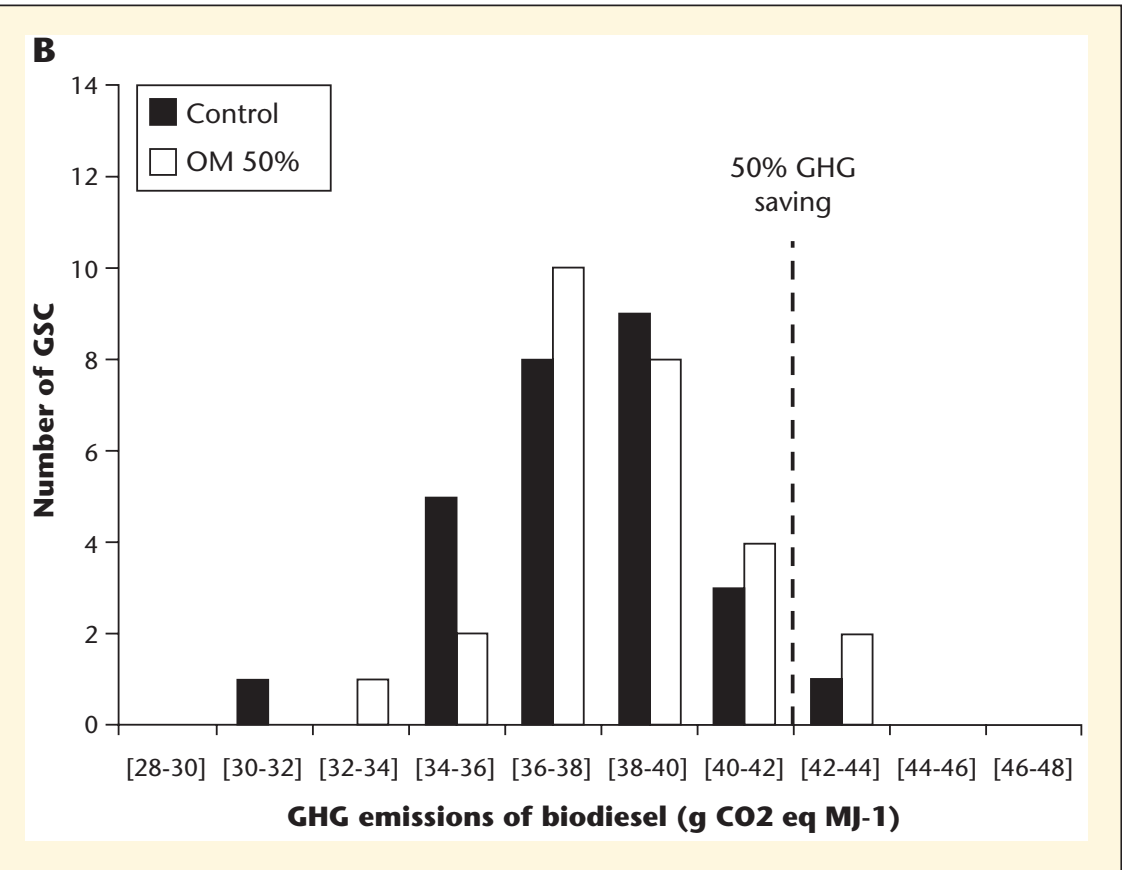

Figure 4. (Continued)

The $N$ fertilizer efficiency of $\mathrm{OM}$ is usually lower than that of mineral $\mathrm{N}$ (Leterme and Morvan, 2012). Hence, the application of OM may not be an effective way of reducing GHG calculated emissions, as long as the $\mathrm{N}_{2} \mathrm{O}$ direct emission factors for organic and mineral $\mathrm{N}$ are the same. These emission factors should be reconsidered, because a unique value for all $\mathrm{OM}$ is probably not relevant. One should expect low emission factors for $\mathrm{OM}$ with slow $\mathrm{N}$ mineralization rates and hence low $\mathrm{N}$ fertilizer efficiencies.

\section{Conclusion}

The study clearly showed that the $50 \%$ GHG saving criteria cannot be achieved

\section{REFERENCES}

BIO IS. Analyses de Cycle de Vie appliquées aux biocarburants de premiere génération consommés en France - Rapport final. Paris: ADEME, 2010. http://agriculture.gouv.fr/ sections/presse5022/communiques/remiseetude-sur-analyse/downloadFile/FichierAttache_2_f0/rapport_final_acv_Biocarburants France_version-definitive.pdf?nocache $=$ 1270718762.51.

De Klein C, Novoa RSA., Ogle S, et al. Chapter $11-\mathrm{N}_{2} \mathrm{O}$ emissions from managed soils, and $\mathrm{CO}_{2}$ emissions from lime and urea application. In: 2006 IPCC Guidelines for National Greenhouse Gas Inventories, 2006.

Gac A, Deltour L, Cariolle M, et al. GES'TIM Guide méthodologique pour l'estimation des impacts des activités agricoles sur l'effet de serre. Paris: Institut de l'élevage, 2009. http:// www.inst-elevage. asso.fr/spip.php?page= article_espace\&id_espace $=933 \& i d \_$article $=$ 17281.

Gaillard G, Hausheer J, Crettaz P. Inventaire environnemental des intrants agricoles en production végétale, base de données pour l'établissement de bilans énergétiques et écologiques en agriculture. Station fédérale de recherches en économie et technologie agricole, 1997.

Godron E. Coûts d'utilisation de machines agricoles. Travaux et innovation 1992; 92/07: 19-23.

Green MB. Energy in pesticide manufacture, distribution and use. In: Helsel ZR (Ed.), Energy in plant nutrition and pest control. Amsterdam (Nederland): Elsevier, 1987.

ITCF. BASEMEQ : base de données mécanisation de I'ITCF. Paris : ITCF, 1995.

Leterme $P$, Morvan T. Mieux valoriser la ressource organique dans le cadre de l'intensification écologique. C R Acad Agric 2012; in press.

Reau R. Bilan énergétique et gaz à effet de serre: perspectives agricoles. OCL 2006; 13 : 117-20. 